\title{
Effects of high fiber ingredients with enzyme/phytoadditive addition on laying hens productive performances, egg nutritional quality and intestinal morphology
}

\author{
Tatiana Dumitra Panaite *1, Maria Gabriela Cornescu${ }^{1}$, Mihaela \\ Saracila1, Mariana Ropota1, Silviu Ionuţ Beia ${ }^{2}$ \\ *corresponding author: tatiana.panaite@ibna.ro
}

${ }^{1}$ National Research-Development Institute for Animal Biology and Nutrition (IBNA), 1 Calea Bucuresti, Balotesti, 077015, Ilfov, Romania;

2 University of Agronomic Sciences and Veterinary Medicine of Bucharest, 59 Mărăşti Boulevard,District 1, 011464, Bucharest, Romania;

\section{ABSTRACT}

Fibre inclusion in laying hen diets it is considered a solution to reduce feed formulation costs by improving nutrients absorption and metabolization within the gastrointestinal tract. A 5-wk study was conducted on 200, Tetra SL layers (28 weeks) randomly allocated in 5 groups (C, E1, E2, E3, E4, respectively), with initial average weights of $1732.26 \pm 109.35 \mathrm{~g} / \mathrm{hen}$, housed (4 hens/cage; 10 cages/group; 40 hens/group). All groups had the same basic feed compound structure (corn, oil, soybean meal and sunflower meal). The conventional diet ( $\mathrm{C}$ group) contained $2780 \mathrm{kcal} / \mathrm{kg}$ Metabolizable energy (ME); $17.5 \%$ Crude protein (CP); $4.39 \%$ Crude fibre (CF). The experimental diets added $16.56 \%$ sunflower meal and $20 \%$ rice bran, increasing the dietary cellulose up to $7 \%$. The fibre digestibility was improved using on E2 (0.015\% enzyme); E3 $(0.015 \%$ phytoadditive) and E4 (0.015\% enzyme $+0.015 \%$ phytoadditive). The high fibre diets had no negative impact on productive performances and egg quality parameters. Yolk cholesterol significantly decreased $(\mathrm{P}<0.05)$ on E1, E3 and E4 groups compared to C, E2 groups. Villi height increased significantly $(\mathrm{P}<0.05)$ on E2 group compared to all other groups. In conclusion, the high dietary crude fibre (7\%), additional enzymes/phyto additives, can improve the nutrient digestibility and intestinal morphology with beneficial effects on health and egg quality.

Keywords: enzyme, fiber, intestinal morphology, laying hens, nutrient digestibility 


\section{INTRODUCTION}

Dietary fiber became a major nutrient component used in poultry formulation diets (Tejeda and Kim, 2021), with beneficial impact on intestinal morphology (Sittiya et al., 2020), organ development (Svihus 2011) and modulation of intestinal microflora (Sadeghi et al., 2015; Singh and Kim, 2021), despite its negative effects on feed intake and nutrient digestibility (Jha and Mishra, 2021). First regarded as a solution to reduce the feeding formulation costs, nowadays is considered an option to limit the inclusion of antibiotic growth promoters (AGP) in monogastric diets and to enhance the poultry health and production parameters (Cimrin et al., 2020; Singh and Kim, 2021).

Zare-Sheibani et al. (2015) consider rice bran as a valuable underused byproduct with a high possibility of improving its feeding value for laying hens nutrition that plays an important role both economics and environmental, reducing the price cost of diets (Sugiharto et al., 2018; Panaite et al., 2020). Nevertheless, its usage in monogastric nutrition it is limited by anti-nutritional factors such as: phytic acid, high fiber content, storage instability, trypsin inhibitor and hemagglutinin, so a heat treatment to alleviate these adverse effects is mandatory (Khan, 2004; Kang et al., 2020). Sunflower meal it is another option to gradually replace the soybean meal into poultry diets, decreasing feed costs and using local, available local feed resources (Alagawany et al., 2018; Tüzün et al., 2020). However as in rice bran case, reducing the fiber content of sunflower meal by processing an increasing of energy density of diets can be noticed (Zhou et al., 2013). High levels of sunflower meal inclusion were reported in several studies (Laudadio et al., 2014; Panaite et al., 2015), without any negative effects on productive performances or egg quality, but nonetheless a higher level than $5 \%$ within diet requires lysine supplementation (Baghban-Kanani et al., 2018).

To improve the nutrients digestion in monogastric animals, especially when high fiber diets are used, enzymes utilization becomes an important key to modulate the intestinal microflora, and consequently change the structural morphology of the intestinal villi (Souza et al., 2014; Yadav and Jha, 2019). Moreover, enzymes inclusion enhances the nutrients digestibility (Kheravii et al., 2018; Zarghi, 2018; Raza et al., 2019) and improves the poultry production (Sateri et al., 2017) and egg quality (Ceylan and Cufadar, Y., 2018).

The purpose of this study was to demonstrate whether or not an increase in the cellulose level (7\%) within experimental groups diets in the presence/absence of the cellulosic enzyme and/or of the plant mixture had any significant influences on poultry performances, nutrient digestibility, and integrity of the intestinal mucosa. 


\section{MATERIALS AND METHODS}

The trial was conducted within experimental halls of National ResearchDevelopment Institute of Animal Biology and Nutrition (IBNA-Balotesti, Romania), approved by the Ethics Commission (no. 52/30.07.2014) and performed in according to the principles of animal welfare rules stated by the EC Directive 63/2010/EEC concerning protection of the animals used for experimental and other scientific purposes.

\section{Experimental birds and management}

A 5-wk study was conducted on 200, Tetra SL layers (28 weeks; $1732.26 \pm 109.35 \mathrm{~g} / \mathrm{hen})$. At the beginning of the trial the laying hen were individually weighed (Table 2) and randomly allocated in 5 groups (C, E1, E2, E3, E4, respectively), housed (4 hens/cage; 10 cages/group; 40 hens/group) in Zucammi battery with following dimensions: $45.5 \mathrm{~cm}$ (front height) $\times 37.5 \mathrm{~cm}$ (back height ) x $55 \mathrm{~cm}$ (total depth) x $58.2 \mathrm{~cm}$ (tiers height) with a floor slope of $14 \%$ ). Each single cage (4 hens) was considered as experimental unit for the statistical analysis. The cage conformation allowed daily observations and collection of feed leftovers and droppings which helped determining the average daily feed intake (g CF/layer/day) and the feed conversion ratio (g CF/kg egg). The battery was placed in a controlled microclimate (temperature $23.34 \pm 1.59^{\circ} \mathrm{C}$ and humidity $63.08 \pm 10.73 \%$ ). Throughout the experimental period, an incandescent lighting was ensured, developed according to a scheme with $16 \mathrm{~h}$ light/8h dark, according to the light program corresponding to the age and categories of birds. Feed and water were administered ad libitum. Throughout the experiment, the laying hens did not receive any immunization or medication.

\section{Dietary treatments}

The compound feeds had the same basic structure (corn, oil, soybean meal and sunflower meal) for all groups. The control group (C) was fed with a conventional diet (2780 kcal/kg ME; $17.5 \% \mathrm{CP} ; 4.39 \% \mathrm{CF}$ ) and compared to C, the experimental diets (E1, E2, E3 and E4) were differentiated by an addition of $16.56 \%$ sunflower meal and $20 \%$ rice bran, which led to an increase in the percentage of dietary cellulose (7\%). The experimental groups E2, E3, E4 had included an enzymatic product (BIOZYM M6000, BIOMIN GmbH, Getzersdorf, Austria) and a plant mixture (Digestarom ${ }^{\circledR}$ Poultry, BIOMIN GmbH, Getzersdorf, Austria) to improve fibre digestibility. The inclusion rate was as follows: E2 (0,015\% Biozym M6000); E3 (0,015\% Digestarom) and E4 (0,015\% Biozym $\mathrm{M} 6000+0,015 \%$ Digestarom $)$. The enzyme contains: beta-xylanase $(6000 \mathrm{U} / \mathrm{g})$ and beta-glucanase $(6000 \mathrm{U} / \mathrm{g})$. The plant mixture is a phytogenic product designed to improve the nutrients utilization and to maintain the gut health. 
Table 1. Ingredients and chemical composition of the diets ( $\%$ as fed)

\begin{tabular}{|c|c|c|c|c|c|}
\hline \multirow{2}{*}{ Ingredients, $\%$, as-fed basis } & \multirow[b]{2}{*}{$\mathrm{C}$} & \multicolumn{4}{|c|}{ Experimental diets } \\
\hline & & E1 & E2 & E3 & E4 \\
\hline Corn & 55.38 & 33.63 & 33.615 & 33.615 & 33.60 \\
\hline Rice bran & - & 20.00 & 20.00 & 20.00 & 20.00 \\
\hline Soybean meal (46 \%) & 22.97 & 14.62 & 14.62 & 14.62 & 14.62 \\
\hline Sunflower meal (34 \%) & 8.00 & 16.56 & 16.56 & 16.56 & 16.56 \\
\hline Vegetal oil & 1.76 & 3.54 & 3.54 & 3.54 & 3.54 \\
\hline L-lysine & - & 0.15 & 0.15 & 0.15 & 0.15 \\
\hline DL-methionine & 0.10 & 0.09 & 0.09 & 0.09 & 0.09 \\
\hline Calcium carbonate & 8.96 & 8.69 & 8.69 & 8.69 & 8.69 \\
\hline Monocalcium phosphate & 1.38 & 1.35 & 1.35 & 1.35 & 1.35 \\
\hline Salt & 0.40 & 0.32 & 0.32 & 0.32 & 0.32 \\
\hline Premix* & 1.00 & 1.00 & 1.00 & 1.00 & 1.00 \\
\hline Enzyme product & - & - & 0.015 & - & 0.015 \\
\hline Phytoadditive & - & - & - & 0.015 & 0.015 \\
\hline Mycotoxin inhibitory & 0.05 & 0.05 & 0.05 & 0.05 & 0.05 \\
\hline Total & 100.00 & 100.00 & 100.00 & 100.00 & 100.00 \\
\hline \multicolumn{6}{|c|}{ Chemical analysis composition, $\%$} \\
\hline Dry matter & 87.11 & 88.06 & 88.06 & 88.06 & 88.06 \\
\hline $\begin{array}{c}\text { Metabolisable energy, } \\
\text { kcal/kg }\end{array}$ & 2780 & 2750 & 2750 & 2750 & 2750 \\
\hline Crude protein & 17.50 & 17.90 & 17.90 & 17.90 & 17.90 \\
\hline Ether extract & 3.55 & 5.11 & 5.11 & 5.11 & 5.11 \\
\hline Crude fiber & 4.39 & 7.00 & 7.00 & 7.00 & 7.00 \\
\hline Calcium & 3.90 & 3.90 & 3.90 & 3.90 & 3.90 \\
\hline Phosphorus & 0.69 & 0.72 & 0.72 & 0.72 & 0.72 \\
\hline Lysine & 0.87 & 0.87 & 0.87 & 0.87 & 0.87 \\
\hline Methionine & 0.40 & 0.38 & 0.38 & 0.38 & 0.38 \\
\hline Met+Cys & 0.70 & 0.67 & 0.67 & 0.67 & 0.67 \\
\hline Threonine & 0.67 & 0.62 & 0.62 & 0.62 & 0.62 \\
\hline Tryptophan & 0.20 & 0.20 & 0.20 & 0.20 & 0.20 \\
\hline Linoleic acid(C18:2) & 2.22 & 2.81 & 2.81 & 2.81 & 2.81 \\
\hline
\end{tabular}

Note: $\mathrm{C}$ - control diet; E1 -diet C with 7\% fiber; E2 = diet C with 7\% fiber and supplemented with enzyme; $\mathrm{E} 3=\operatorname{diet} \mathrm{C}$ with 7\% fiber and supplemented with phytoadditive; $\mathrm{E} 4=\operatorname{diet} \mathrm{C}$ with $7 \%$ fiber and supplemented with enzyme + phytoadditive; ${ }^{*}$ Per kg premix contained: $1350000 \mathrm{IU} / \mathrm{kg}$ vitamin A; $300000 \mathrm{IU} / \mathrm{kg}$ vitamin D3; $2700 \mathrm{IU} / \mathrm{kg}$ vitamin E; $200 \mathrm{mg} / \mathrm{kg}$ vitamin $\mathrm{K} ; 200 \mathrm{mg} / \mathrm{kg}$ vitamin B1; $480 \mathrm{mg} / \mathrm{kg}$ vitamin B2; $1485 \mathrm{mg} / \mathrm{kg}$ pantothenic acid; $2700 \mathrm{mg} / \mathrm{kg}$ nicotinic acid; $300 \mathrm{mg} / \mathrm{kg}$ vitamin B6; $4 \mathrm{mg} / \mathrm{kg}$ vitamin B7; $100 \mathrm{mg} / \mathrm{kg}$ vitamin B9; $1.8 \mathrm{mg} / \mathrm{kg}$ vitamin B12; $2500 \mathrm{mg} / \mathrm{kg}$ vitamin C; $7190 \mathrm{mg} / \mathrm{kg}$ manganese; $6000 \mathrm{mg} / \mathrm{kg}$ iron; $600 \mathrm{mg} / \mathrm{kg}$ copper; $6000 \mathrm{mg} / \mathrm{kg}$ zinc; 50 $\mathrm{mg} / \mathrm{kg}$ cobalt; $114 \mathrm{mg} / \mathrm{kg}$ iodine; $18 \mathrm{mg} / \mathrm{kg}$ selenium; 
The diets formulation (Table 1) was developed using HYBRIMIN® Futter 5, according with the laying hens' feeding requirements (NRC, 1994). All diets were isocaloric and isonitrogenous.

\section{Sample collection and procedures}

All productive parameters: body weight (BW, g/layer); average daily feed intake (ADFI, g CF/head/day); feed conversion rate (FCR, $\mathrm{kg} \mathrm{CF} / \mathrm{kg}$ egg); laying production (\%); average egg weight (g) and eggs weight classification were registered during the entire experimental period.

During the $5^{\text {th }}$ experimental week, daily records of feed ingested and droppings were registered to establish the apparent absorption of cellulose coefficients. These values, altogether with the feed and droppings nutrient concentrations data allowed the nutritional balance calculations to be performed The apparent absorption coefficient was calculated according to Khan et al. (2004) using the formula:

$$
\% \text { Absorption coefficient }=\frac{\text { Nutrient absorbed }(\mathrm{g})}{\text { Nutrient ingested }(\mathrm{g})} \times 100
$$

During the last week 18 eggs/group were collected to determine egg quality parameters. Prior to the eggs being broken, measurements were carried out to determine the quality of the egg shell: eggshell thickness (Egg Shell Thickness Gauge, ORKA Technology LLC, Wanchai, Hong Kong) and eggshell breaking strength (Egg Force Reader, ORKA Technology LLC, Wanchai, Hong Kong). All eggs were broken and the egg components were weight individually (egg white, egg yolk, shell) using an analytical scale (Kerm scales, precision 0.001); colour intensity, on La Roche colour fan (1-15) measured with an Egg Analyzer TM; egg freshness, measured by the value of the Haugh indicator and points of freshness evaluation (Egg Analyzer TM, ORKA Technology LLC, Wanchai, Hong Kong). After then, six samples of yolk (3 eggs/sample/group), dried at $65^{\circ} \mathrm{C}$, were assayed for the yolk cholesterol content.

After the 5-wk study was finished, 6 blood samples/group were collected from the wing vein, in vacutainers with EDTA anticoagulant for haematology analyses ( $3 \mathrm{~mL} / \mathrm{bird}$ ) and for biochemistry analyses in the Li-heparin vacutainers $(2 \mathrm{~mL} /$ bird $)$. After collection, the blood was centrifuged by inverting the tubes 4-5 times to ensure homogenization of the anticoagulant with the collected blood. Haematological analyses were determined by flow cytometry with peroxidase reaction and laser detection, and biochemistry analyses were determined by spectrophotometric method.

After the slaughtering, liver, bile and spleen samples were taken to determine cholesterol levels. 
Intestinal samples (jejunum 5-6 cm) were collected for histological analysis. The intestinal morphometry (villi height, crypt depth and muscle thickness) was measured using an Olympus BX 41 microscope equipped with a digital camera (Olympus U-TV1X-2). The villus length measurements was done from the villuscrypt junction up to the villus tip and the crypt depth measurements from the crypt base to the villus-crypt junction. Villus: crypt ratio was calculated by dividing the villus height by crypt depth.

\section{Chemical Analyses}

The crude fibre analysis was determined using the intermediary filtration method, according to Regulation (CE) no. 152/2009 and standard SR EN ISO 6865:2002, whose principle consists of the solubilisation of all nutrients other than cellulose by successive boiling with sulfuric acid and sodium hydroxyde solutions, so the residue formed is filtered, dried, calcined and weighed, using the FIBERTEC 2010 - Tecator system (Sweden).

Gas chromatographic method according with AOAC International Official Method (1996) 99410 was used to determine the cholesterol level of collected samples (yolk, liver and bile) by samples' saponification, followed by petroleum ether extraction and pouring on chloroform after concentration. The sample is split in GC (gas chromatograph Perkin Elmer Clarus-500; -FID flame ionization detector) then separated by chromatography column (HP-5 capillary $30 \mathrm{~m}$, $0.32 \mathrm{~mm}$ ID, $0.1 \mathrm{um} . \mathrm{df}$ thick film) then compared with standard chromatograms by measuring peak area, the cholesterol concentration being determined.

\section{Statistical Analyses}

The treatments effects on productive performances, egg quality parameters, egg cholesterol content, liver and bile, nutrient digestibility and intestinal mucosa integrity were analysed using variance analysis (ANOVA) by StatView for WINDOWS (SAS, version 6.0). The Tukey's multiple range test was applied when mean differences were identified $(\mathrm{P}<0.05)$.

\section{RESULTS AND DISCUSSION}

\section{Layer performances and egg quality}

The high level dietary inclusion of cellulose (7\%) influenced the layers' performances and egg quality parameters (table 2).

At all experimental groups it was noticed, a decreasing trend of BW $(\mathrm{P}=0.0520)$ compared to the $\mathrm{C}$ group diet $(4.39 \% \mathrm{CF})$, significant differences being recorded only in the case of group E3 $(p=0.0201)$. The results could be correlated with a significantly decrease $(\mathrm{P}<0.0001)$ of ADFI $(\mathrm{g} /$ day $)$ at all experimental groups compared to $\mathrm{C}$ group. Similar results concerning BW decreasing were recorded by Röhe et al. (2019) using 10\% lignocellulose low 
levels of dietary energy and nutrients. Also, the dietary addition of rice bran $(20 \%)$ and sunflower meal (17\%), both rich sources of cellulose, reduced significantly $(\mathrm{P}<0.0001)$ ADFI within all experimental groups (table 2$)$.

Table 2. Effect of diets with $7 \%$ dietary fiber on layer performance, egg quality parameters and egg size classification (average values/group)

\begin{tabular}{|c|c|c|c|c|c|c|c|}
\hline \multirow{2}{*}{ Specification } & \multirow[b]{2}{*}{$\mathrm{C}$} & \multicolumn{4}{|c|}{ Experimental diets } & \multirow[b]{2}{*}{ SEM } & \multirow{2}{*}{$\begin{array}{c}\mathrm{p}- \\
\text { value }\end{array}$} \\
\hline & & E1 & E2 & E3 & E4 & & \\
\hline \multicolumn{8}{|l|}{$\begin{array}{c}\text { Layer } \\
\text { performances }\end{array}$} \\
\hline $\begin{array}{l}\text { Initial weight } \\
\text { (g/layer) }\end{array}$ & 1748 & 1747 & 1735 & 1700 & 1731 & 10.197 & 0.5908 \\
\hline $\begin{array}{c}\text { Final weight } \\
\text { (g/layer) }\end{array}$ & $1835^{\mathrm{a}}$ & $1787 \mathrm{ab}$ & $1810^{\mathrm{ab}}$ & $1759 \mathrm{~b}$ & $1776^{\mathrm{ab}}$ & 10.266 & 0.0520 \\
\hline $\begin{array}{l}\text { Average daily feed } \\
\text { intake, (g/day) }\end{array}$ & $124.34^{\mathrm{a}}$ & $118.20^{\mathrm{b}}$ & $118.15^{b}$ & $117.94^{b}$ & $116.74^{b}$ & 0.504 & $<0001$ \\
\hline $\begin{array}{c}\text { Feed conversion } \\
\text { rate, } \\
\text { (g feed/g egg) }\end{array}$ & $2.13^{\text {bd }}$ & $2.11^{\mathrm{b}}$ & $2.34^{\mathrm{ac}}$ & $2.03^{b}$ & $2.24^{c}$ & 0.020 & $<0001$ \\
\hline $\begin{array}{c}\text { Egg production, } \\
(\%)\end{array}$ & $94.98^{\mathrm{ab}}$ & $93.28^{\mathrm{ab}}$ & $92.05^{b}$ & $96.35^{a}$ & $95.09 \mathrm{ab}$ & 0.657 & 0.0262 \\
\hline Egg weight, (g) & $62.81^{\mathrm{a}}$ & $61.39 \mathrm{bc}$ & $61.68^{b}$ & $61.29 \mathrm{bc}$ & $60.86^{c}$ & 0.133 & $<0001$ \\
\hline \multicolumn{8}{|c|}{ Egg quality parameters } \\
\hline $\begin{array}{l}\text { Eggshell thickness, } \\
\text { (mm) }\end{array}$ & $0.34^{b}$ & $0.35^{\mathrm{ab}}$ & $0.35^{\mathrm{ab}}$ & $0.36^{\mathrm{a}}$ & $0.35^{\mathrm{ab}}$ & 0.003 & 0.0814 \\
\hline $\begin{array}{l}\text { Eggshell breaking } \\
\text { strength }(\mathrm{kgF})\end{array}$ & $3.95^{\mathrm{a}}$ & $3.65^{b}$ & $4.05^{a}$ & $4.10^{\mathrm{a}}$ & $3.81^{\mathrm{a}}$ & 0.049 & 0.0187 \\
\hline Yolk color (value) & $3.53^{\mathrm{a}}$ & $2.50^{\mathrm{b}}$ & $2.61^{b}$ & $2.14^{c}$ & $2.25^{\mathrm{c}}$ & 0.065 & $<0001$ \\
\hline Haugh unit (value) & 62.36 & 61.55 & 59.00 & 58.92 & 62.07 & 0.687 & 0.3079 \\
\hline $\begin{array}{c}\text { Egg size } \\
\text { classification }\end{array}$ & & & & & & & \\
\hline $\begin{array}{c}\text { Total eggs (pieces) } \\
\text { - of which } \\
(\%):\end{array}$ & 644 & 630 & 622 & 653 & 648 & & \\
\hline XL (>73 g) & 1.86 & 1.27 & 1.13 & 1.53 & 0.46 & & \\
\hline L (63-73 g) & 46.12 & 30.95 & 35.69 & 32.77 & 36.42 & & \\
\hline$M(53-63 \mathrm{~g})$ & 50.62 & 63.81 & 61.58 & 63.40 & 61.88 & & \\
\hline $\mathrm{S}(<53 \mathrm{~g})$ & 1.40 & 3.97 & 1.61 & 2.30 & 1.23 & & \\
\hline
\end{tabular}

Note: $\mathrm{C}$ - control diet; E1 -diet C with 7\% fiber; E2 = diet C with 7\% fiber and supplemented with enzyme; E3 = diet $\mathrm{C}$ with 7\% fiber and supplemented with phytoadditive; $\mathrm{E} 4=\operatorname{diet} \mathrm{C}$ with $7 \%$ fiber and supplemented with enzyme + phytoadditive; SEM, standard error of the mean;

a-cMean values within a row having different superscripts are significantly different at $\mathrm{P}<0.05$;

According to Guzman et al. (2016) using two fiber sources (2\% cereal straw, $4 \%$ sugar beet pulp) with different energy content $(2,650$ vs. $2,750 \mathrm{kcal}$ 
AMEn $/ \mathrm{kg}$ ) noticed that the hens fed higher energy diet had a lower ADFI $(\mathrm{P}<0.001)$, a better FCR $(\mathrm{P}<0.01)$, and a greater body weight gain $(\mathrm{P}<0.05)$ than hens fed the low energy diet but egg production and egg weight were not affected. Röhe et al. (2019) experimented a low energy and nutrient dietary content containing 10\% lignocellulose (LC) and noticed significant $(\mathrm{p}<0.05)$ lower BW, an increased $(\mathrm{p}<0.001)$ ADFI on LC-fed hens but the overall experimental results showed a laying performance improvement and a reduction of body fat content. Contrary to our results Sozcu and Ipek (2020) reported no significant effects of lignincellulose (LS) supplementation $(0.5 \mathrm{~kg}, 1 \mathrm{~kg}$, and $2 \mathrm{~kg}$ LS per ton of feed) regarding ADFI.

The FCR on E2 group was significant higher $(\mathrm{P} \leq 0.0001)$ compared to $\mathrm{C}, \mathrm{E} 1$ and E3 groups. The lowest FCR and the best laying intensity were noticed at E3 group. Röhe et al., (2019) obtained an improved (P<0.05) FCR, 2.63 vs. 2.89 when using dietary LC $(10 \%)$.

The egg production registered significant differences $(\mathrm{P}>0.05)$ between E3 and E2 groups. Similar results were obtained by authors as Sousa et al., 2019 (wheat bran/ soybean hulls/coffee husks with or without xylanase), Wang et al., 2021 (7.5 and 15\% of California type hulls/prime hulls) and Selim and Hussein, 2020 (3\%, 5\%, and 7\% sugar beep pulp), who noticed no negative effects of high dietary fibre inclusion rate on egg production concluding that laying hens are becoming more tolerant to dietary fibers.

Abdulah et al. (2015) registered a significantly $(\mathrm{P}<0.05)$ improved egg production with $5.9 \% \mathrm{CF}$ (provided by $14 \%$ sunflower meal). Also, Incharoen and Maneechote (2013) recorded a hen-day egg production higher by $2.56 \%$ (6\% whole rice hulls) and by $1.48 \%$ (3\% whole rice hulls) compared to C group, without any adverse effects on the main egg quality parameters.

Contrary, Samli et al. $(2006)$ obtained a significantly $(\mathrm{P}<0.05)$ reduced egg production from 93.6 to $87.8 \%$, on $15 \%$ dietary rice bran inclusion responsible also for the decreased feed intake. Also, Praes et al. (2014) experimented three fiber sources (cottonseed, soybean and rice hulls) and two dietary crude protein levels $(12 \%$ and $16 \%)$ on Isa Brown layers and noticed negative effects on production parameters. Alagawany et al. (2015) stated that a content higher than $8.9 \%$ CF $(26 \%$ SFM) will effect negatively the egg production.

As present within Table 2, the egg weight results of experimental groups highly decreased $(\mathrm{P}<0.0001)$ compared to $\mathrm{C}$ group.

Concerning egg weight parameter, highly significant differences $(\mathrm{P}<0.0001)$ were observed in $\mathrm{C}$ group compared to all experimental groups probably due to a higher body weight, being already demonstrated the correlation between body weight and egg weight and a higher average feed intake. The same results were obtained by Abdulah et al. (2015) who observed that the experimental groups recorded a significantly lower average egg weight than that control diet. On the other hand, Sousa et al., 2019 found no differences $(\mathrm{P}>0.05)$ on egg weight 
parameter regardless the dietary fiber source included or the presence/absence of enzyme, but the eggshell thickness recorded significant higher values $(\mathrm{P}<0.05)$ for wheat bran group and soybean hulls compared to coffee husks. Similar results were obtained in our experiment where the eggshell thickness values were higher for all experimental groups compared to $\mathrm{C}$ group but without statistically difference $(\mathrm{P}>0.05)$. Groups $\mathrm{C}, \mathrm{E} 2$ and E3 registered the highest value for eggshell breaking strength, statistically significant $(\mathrm{P}<0.0187)$ compared with $\mathrm{E} 1$.

The highest value for yolk colour was obtained in $\mathrm{C}$ group highly statistically $(\mathrm{P}<0.0001)$ compared with all other experimental groups. We presume that the best yolk pigmentation results of $\mathrm{C}$ group can be explained by the high inclusion of corn rate $(55.38 \%$ vs $33.63 \%)$ compared with experimental groups, and therefore a reduction of xanthophylls level and a lower of yolk colour intensity. Wang et al. (2021) using dietary prime and California hulls $(7.5 \%$ and $15 \%$ for each type) noticed no effects on egg weight, Haugh unit, shell thickness nor albumen weight.

\section{Cholesterol concentration within eggs, serum and organs}

Using high fiber diets (7\%) influenced egg yolk cholesterol concentrations, serum and organs as presented in table 3.

Table 3. Effect of diets with 7\% dietary fiber on cholesterol concentration in the egg yolk, serum and organs (liver, spleen, bile)

\begin{tabular}{|c|c|c|c|c|c|c|c|}
\hline \multirow{2}{*}{ Specification } & \multicolumn{5}{|c|}{ Experimental diets } & \multirow{2}{*}{ SEM } & \multirow{2}{*}{$\mathrm{p}$-value } \\
\hline & $\mathrm{C}$ & E1 & E2 & E3 & E4 & & \\
\hline \multicolumn{8}{|c|}{ Eggs cholesterol, g/100g dry yolk } \\
\hline $\begin{array}{c}\text { Yolk } \\
\text { cholesterol }\end{array}$ & $1.31^{\mathrm{a}}$ & $1.15^{b}$ & $1.28^{\mathrm{a}}$ & $1.15^{b}$ & $1.10^{\mathrm{b}}$ & 0.021 & 0.0082 \\
\hline \multicolumn{8}{|c|}{ Serum cholesterol, $\mathrm{mg} / \mathrm{dl}$} \\
\hline Serum & $145.00^{\mathrm{a}}$ & $132.50^{\mathrm{ac}}$ & $119.00^{\mathrm{ac}}$ & $85.75^{\mathrm{b}}$ & $106.75^{b c}$ & 6.358 & 0.0040 \\
\hline \multicolumn{8}{|c|}{ Organs cholesterol, g/100 g DM } \\
\hline Liver & $0.58^{\mathrm{ac}}$ & $0.52^{\mathrm{bc}}$ & $0.61^{\mathrm{a}}$ & $0.51^{\mathrm{b}}$ & $0.46^{\mathrm{b}}$ & 0.015 & 0.0035 \\
\hline Bile & 0.16 & 0.21 & 0.19 & 0.16 & 0.17 & 0.010 & 0.5576 \\
\hline Spleen & $0.54^{\mathrm{b}}$ & $0.51^{\mathrm{b}}$ & $0.48^{b}$ & $0.44^{\mathrm{b}}$ & $0.67^{a}$ & 0.025 & 0.0211 \\
\hline
\end{tabular}

Note: $\mathrm{C}$ - control diet; E1 -diet C with 7\% fiber; E2 = diet C with 7\% fiber and supplemented with enzyme; $\mathrm{E} 3=\operatorname{diet} \mathrm{C}$ with 7\% fiber and supplemented with phytoadditive; $\mathrm{E} 4=\operatorname{diet} \mathrm{C}$ with $7 \%$ fiber and supplemented with enzyme + phytoadditive; SEM, standard error of the mean;

a-cMean values within a row having different superscripts are significantly different at $\mathrm{P}<0.05$

Haught unit was not influenced by the $7 \% \mathrm{CF}$ inclusion, and the highest values, without statistically difference $(\mathrm{P}>0.05)$ were registered for $\mathrm{C}$ and $\mathrm{E} 4$ groups. Braz et al. (2011) did not observe any differences on Haugh units and eggshell percentage when fed diets with different neutral detergent fiber (NDF) levels to layers. Hassan et al. (2013) using above 3 \% CF noticed higher $(\mathrm{P}<0.05)$ 
values of albumen height and shape index values with no significant differences in yolk index (\%) and Haugh units.

Table 3 shows a significant decrease $(\mathrm{P}<0.05)$ within yolk cholesterol concentration in all experimental groups, fed high fibre, except for group E2 group (with enzyme). The lowest value for cholesterol concentration determined in egg yolk was obtained in E4 group (with the addition of $0.015 \%$ enzyme and $0.015 \%$ phytoadditive), significantly lower $(\mathrm{P} \leq 0.05)$ compared to $\mathrm{C}$ and $\mathrm{E} 2$ groups (with enzyme). The results obtained by Shi et al., (2012) showed that the egg yolk cholesterol percentage from hens that included dietary sunflower meal was significantly $(\mathrm{P} \leq 0.05)$ lower compared to egg yolk cholesterol values obtained from conventional diet feeding. Laudadio et al., (2014) showed that the inclusion of low-fiber sunflower meal $(160 \mathrm{~g} / \mathrm{kg}$ of diet) in the diet of ISA Brown laying hens led to a significant decrease $(\mathrm{P} \leq 0.05)$ of yolk and serum cholesterol. Pantaya et.al (2020) experimented inclusion of wheat bran $10 \%, 20 \%, 30 \%$ respectively into laying ducks diet (containing already rice bran $26 \%, 16 \%$ and $20 \%$ respectively). The results obtained showed a lower cholesterol level $(\mathrm{P}<0.05)$ in all wheat bran supplementation compared to control diet but no difference diets with different inclusion percentages of with wheat bran. Hassan et al. (2013) investigated 3\% 4\%, 5\%, 6\% levels of CF dietary (wheat bran and alfalfa meal) inclusion under drinking natural saline water on egg yolk cholesterol and at $6 \%$ CF inclusion had a significant $(\mathrm{P}<0.05)$ decrease of egg yolk concentrations of cholesterol, total cholesterol, total lipids, triglycerides, phospholipids, low-density lipoproteins (LDL).

The serum samples showed significantly lower values $(\mathrm{P} \leq 0.05)$ for cholesterol within E3 and E4 groups. Group E3 (with phytoadditive) showed the lowest value of cholesterol concentration expressed in serum samples. Menge et al. (2012) introduced 4.1 to $17.7 \% \mathrm{CF}$ and observed a reduction in serum cholesterol but an increase in egg yolk cholesterol. Zhang et al., (2005) explained that the role of cellulose is to direct bile acid from the intestine to the body, causing the formation of bile acids by extracting cholesterol from the blood, which causes a decrease of the cholesterol content. Hassan et al. (2013) obtained a significant decrease in serum total lipids, cholesterol, triglyceride and HDL values with increasing $(4 \%, 5 \%, 6 \%) \mathrm{CF}$ levels.

The lowest cholesterol liver concentration was significantly reduced $(\mathrm{P}<0.05)$ in E3 and E4 groups. However, in the bile samples collected from E1 group, a higher cholesterol concentration was found compared to the other experimental groups, but without any statistical difference. In general, increasing cholesterol concentration in bile could mean its release through bile, main way to eliminate cholesterol from the body (Luo et al., 2020). The data are corroborated with those obtained in the spleen samples (table 3). Groups E1, E2, E3 had the lowest cholesterol concentration in spleen $(\mathrm{P}<0.05)$ compared with $\mathrm{E} 4$. 
Figure 1 shows a high crude fiber absorption coefficients, especially on E2, where $0.015 \%$ enzyme was added and E4, where $0.015 \%$ enzyme $+0.015 \%$ phytoadditive was included compared with C, E1 and E3 groups. This result confirms that enzyme and combination: enzyme and phytoadditive succeeded to degrade intestinal cellulose. Our results are in according with Agyekum and Nyachoti (2017) who concluded that providing exogenous fiber-degrading enzymes improves the feeding value of dietary high-fiber with beneficial effects on nutrient absorption. Another hypothesis for the absorption of cellulose as Hetland et al. (2005) stated could be due to the cellulose insoluble fractions ingestion, probably through an increased gastroduodenal reflux which facilitates the nutrients digestion. Also, Lin and Olukosi (2021) stated that exogenous enzymes added to high-fiber poultry diets may have a beneficial effect on digestive tract.

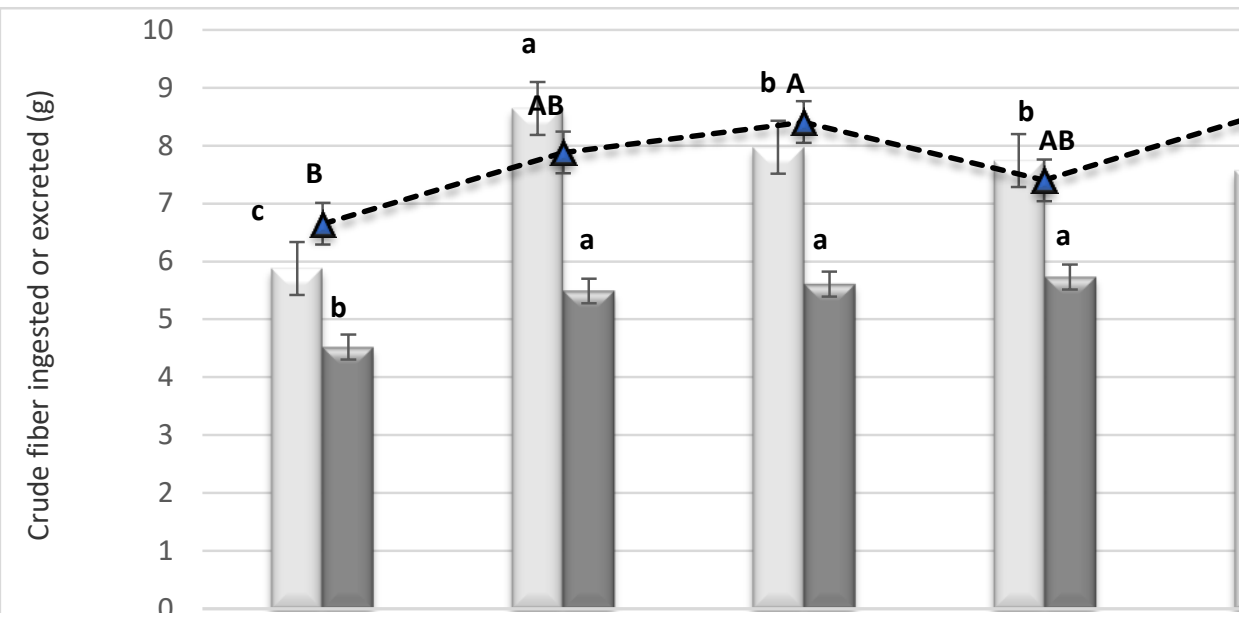

Figure 1. Intake and excretion of crude cellulose correlated with the apparent absorption coefficient of cellulose in the diet: $\mathrm{C}$ - control diet; $\mathrm{E} 1-\operatorname{diet} \mathrm{C}$ with $7 \%$ fiber; $\mathrm{E} 2=\operatorname{diet} \mathrm{C}$ with $7 \%$ fiber and supplemented with enzyme; $\mathrm{E} 3=\operatorname{diet} \mathrm{C}$ with $7 \%$ fiber and supplemented with phytoadditive; $\mathrm{E} 4=$ diet $\mathrm{C}$ with $7 \%$ fiber and supplemented with enzyme + phytoadditive; ${ }^{\mathrm{a}-}$ ${ }^{c}$ Mean values within columns having different superscripts are significantly different at $\mathrm{P}<0.05$; ${ }^{\mathrm{A}-\mathrm{B}}$ Mean values within line having different superscripts are significantly different at $\mathrm{P}<0.05$;

The experimental diets rich in cellulose have influenced the morphological integrity of the intestinal mucosa. Group E2 (7\% fiber $+0.015 \%$ enzyme) presented the highest value $(\mathrm{P}<0.05)$ for the villi height and the villi heigh:crypt ratio compared to the other experimental groups. In the same time, E2 group registered the lowest value $(P>0.05)$ of the crypt depth and also the villi height was correlated with the muscle thickness which registered the highest value $(\mathrm{P}<0.05)$ compared with all other groups. Our results are in according with 
Yang et al., (2008) which considers that the presence of the enzyme determine frequently the increase of the villi. Koçer et al. (2021) reported an increased villus weight, a height:crypt depth ratio with the inclusion of $47 \mathrm{~g}$ sunflower meal $/ \mathrm{kg}$ diet, but decreased with increased level of sunflower meal $(97 \mathrm{~g}$ sunflower meal/kg) in Nick Chick white laying hens. Jha and Mishra (2021) confirm that a higher villus height to crypt depth ratio is estimated as an indicator of a better function and development of the intestinal mucosa. Therefore, it is fundamental to decide the ideal concentration and source of dietary fiber to enhance GIT.

Table 4. Morphological integrity of the intestinal mucosa (average values/group)

\begin{tabular}{|c|c|c|c|c|c|c|c|}
\hline \multirow{2}{*}{ Specification } & \multicolumn{5}{|c|}{ Experimental diets } & \multirow{2}{*}{ SEM } & \multirow{2}{*}{ p-value } \\
\hline & $\mathrm{C}$ & E1 & E2 & E3 & E4 & & \\
\hline $\begin{array}{l}\text { Villi height } \\
\qquad(\mu \mathrm{m})\end{array}$ & $617.50^{\mathrm{b}}$ & $577.00^{\mathrm{b}}$ & $718.00^{\mathrm{a}}$ & $580.00^{\mathrm{b}}$ & $633.00^{\mathrm{b}}$ & 1.49 & 0.0025 \\
\hline $\begin{array}{l}\text { Crypt depth } \\
\qquad(\mu \mathrm{m})\end{array}$ & $206.70^{a}$ & $129.00^{c}$ & $121.00^{c}$ & $126.00^{c}$ & $156.00^{\mathrm{b}}$ & 4.896 & $<0001$ \\
\hline $\begin{array}{c}\text { Muscle } \\
\text { thickness } \\
(\mu \mathrm{m})\end{array}$ & 205.00 & 175.00 & 240.00 & 185.00 & 170.00 & 14.717 & 0.6017 \\
\hline $\begin{array}{l}\text { Villi height: } \\
\text { crypto depth } \\
\text { ratio (V:C) }\end{array}$ & 2.99 & 4.48 & 5.91 & 4.60 & 4.06 & & \\
\hline
\end{tabular}

Also, Awad et al. (2006) found that a greater villus height contributed to an increased surface area for greater absorption of available nutrients. JimenezMoreno et al. (2011) reported an improvement in villi height in broilers (15 days old) fed ratios that included 2.5\% pea husks. Also, Teirlynck et al. (2009) stated that the length of villi shows their absorptive capacity, and trials have illustrated that non-starch polysaccharides (s-NSP) have a harmful impact on villus high. Some authors reported a decrease in villi height when using high levels of crude fibre provided from sunflower meal (Kalmendal et al., 2011) or sugar beet pulp (Sadeghi et al., 2015) in laying hens diet. Contrary to previously results Praes et al. (2011) reported higher villus height, crypt depth development and a reduced $\mathrm{VH} / \mathrm{CD}$ ratio values when fed rice husks (5\% CF and 16\% CP). Souza et al. (2014) found that using 3.2\% CF, xylanase enzyme $(0.01 \%)$ and $2800 \mathrm{kcal} / \mathrm{kg}$, the crypt depth and villus:crypt ratio from jejunum were significant influenced 
$(p<0.05)$ due to the interaction between energy level and enzyme supplementation.

In our study crypt depth values for the experimental groups were significantly decreased $(\mathrm{P}<0.0001)$ compared to $\mathrm{C}$ group. Even more at $\mathrm{E} 4$ group fed with high-fibre diet supplemented with enzyme + phytoadditive, it was observed a statistically higher $(\mathrm{p}<0.05)$ value for crypt depth compared to the other 3 experimental groups (E1, E2, E3). Crypt depth values show the proliferative activity of epithelial cells (Geyra et al. 2001). Willing \& Van Kessel (2007) show that the low crypt depth values is determined by a metabolic cost reduction of the intestinal epithelium turnover.

The development of intestinal crypt influences the crypt-cell turnover maintenance rate and intestinal maturation. Therefore as Geyra et al. (2001) show deeper crypts result in an increased intestinal absorption surface area.

Iji et al. (2001) noticed no differences in cell proliferation of broilers' intestinal mucosa when using dietary high viscosity fiber sources. An increasing of crypt depth was found when using s-NSP which increases the renewal cellular rate (Wu et al., 2004b). Xu et al., 2003 demonstrated that deeper crypt means a rapid tissue turnover which demands for new tissus which affect the animal productivity.

In our study, the villi height:crypto depth ratio registered the highest values to experimental groups compared with $\mathrm{C}$ group. Again, E2, among the experimental groups had the highest value. An improvement in the villus height:crypt depth ratio in broilers were reported also by Sittiya et al. (2016) and Jiménez-Moreno et al. (2011) when using whole rice grain and pea hulls . The villi height:crypt depth ratio is important to estimate the digestive capacity of the small intestine according to Mateos et al. (2012).

\section{CONCLUSION}

According to the experimental results, using high dietary fiber (additional enzymes/phytoadditives) in laying hens can improve the morphological integrity of the intestinal mucosa, with beneficial effects on cholesterol concentrations from yolk, serum, liver and spleen without negative impact on productive performances and egg quality parameters.

\section{ACKNOWLEDGEMENTS}

This research was funded by the Ministry of Research, Innovation and Digitization, Project PN 19090102. 


\section{REFERENCES}

Abdallah, A.G., Beshara, M.M., Ibrahim, A.F., 2015. Effect of different levels and sources of dietary fiber on productive and economical performance in local laying hens 1-during growing period and subsequent laying performance. Egypt. Poult. Sci. 35(1), 367-398.

Agyekum, A.K., \& Nyachoti, C.M., 2017. Nutritional and metabolic consequences of feeding high-fiber diets to swine: a review. Engineering. 3(5), 716-725.

Alagawany, M., Farag, M. R., Abd, El-Hack M. E., \& Dhama, K., 2015. The practical application of sunflower meal in poultry nutrition. Advances in Animal Veterinary Science. 3(12), 634-648.

Alagwany, M., Attia, A., Ibrahim, Z., Abd el-hack, M., Arif, M., \& Emam M., 2018. The influences of feeding broilers on graded inclusion of sunflower meal with or without Avizyme on growth, protein and energy efficiency, carcass traits, and nutrient digestibility. Turkish Journal of Veterinary and Animal Sciences. 42(3), 168-176.

Awad, W. A., Böhm, J., Razzazi-Fazeli, E., Ghareeb, K., \& Zentek J., 2006. Effect of addition of a probiotic microorganism to broiler diets contaminated with deoxynivalenol on performance and histological alterations of intestinal villi of broiler chickens. Poultry Science. 85(6), 974-979.

Baghban-Kanani, P., Hosseintabar-Ghasemabad, B., Azimi-Youvalari, S., Seidavi, A., Ayaşan, T., Laudadio, V., \& Tufarelli, V. 2018. Effect of different levels of sunflower meal and multi-enzyme complex on performance, biochemical parameters and antioxidant status of laying hens. South African Journal of Animal Science, 48(2), 390-399.

Braz, N.M., 2011. Fibra na ração de crescimento e seus efeitos no desempenho de poedeiras nas fases de crescimento e postura. Revista Brasileira de Zootecnia. 40(12), 2744-2753.

Ceylan, M. E., \& Cufadar, Y., 2018. Effect of Enzyme Supplementation to Laying Hens Diets Containing Different Levels of Sunflower Seed Meal on Performance and Egg Quality. Selcuk Journal of Agriculture and Food Sciences. 32(3), 402-406.

Cimrin, T., Tunca, R.I., Avsaroglu, M.D., Ayasan, T., Kücükersan, S., 2020. Effects of an antibiotic and two phytogenic substances (cinnamaldehyde and 1,8cineole) on yolk fatty acid profile and storage period-associated egg lipid peroxidation level. Revista Brasileira de Zootechnia. 49:e20190270.

Geyra, A., Z. Uni, and Sklan D., 2001. Enterocyte dynamics and mucosal development in the post-hatch chick. Poult. Sci. 80:776-782.

Guzmán, P., Saldaña, B., Bouali, O., Cámara, L., Mateos, G.G., 2016. Effect of level of fiber of the rearing phase diets on egg production, digestive tract traits, and body measurements of brown egg-laying hens fed diets differing in energy. Poultry Science. 95 (8), 1836-1847. 
Hassan, M., Morsy, A., Hasan, A., 2013. Egg yolk cholesterol and productive performance of laying hens influenced by dietary crude fiber levels under drinking natural saline water. Journal of Animal and Poultry Production. 4(3), 161-176.

Hetland, H., Svihus, B., Choct, M., 2005. Role of insoluble fiber on gizzard activity in layers. Journal Applied Poultry Research, 14:38-46.

Iji, P. A., Saki, A. A., and Tivey, D. R., 2001. Intestinal development and body growth of broiler chicks on diets supplemented with non-starch polysaccharides. Anim. Feed Sci. Technol. 89:175-188.

Röhe, I., Urban, J., Dijkslag, A., Paske, J. \& Zentek, J., 2019. Impact of an energyand nutrient-reduced diet containing $10 \%$ lignocellulose on animal performance, body composition and egg quality of dual purpose laying hens. Archives of Animal Nutrition. 73:1, 1-17.

Incharoen, T., \& Maneechote, P., 2013. The effects of dietary whole rice hull as insoluble fiber on the flock uniformity of pullets and on the egg performance and intestinal mucosa of laying hens. American Journal of Agricultural and Biological Sciences. 8(4), 323-329.

Jha, R., \& Mishra, P., 2021. Dietary fiber in poultry nutrition and their effects on nutrient utilization, performance, gut health, and on the environment: a review. J Animal Sci Biotechnol. 12(1), 1-16.

Jiménez-Moreno, E., Romero, C., Berrocoso, J., Frikha, M., Gonzalez-Mateos, G., 2011. Effects of the inclusion of oat hulls or sugar beet pulp in the diet on gizzard characteristics, apparent ileal digestibility of nutrients, and microbial count in the ceca in 36 day old broilers reared on floor. St. Louis, EEUU: In 100 th Annual Meeting Poultry Science Association.

Kalmendal, R., Elwinger, K., Holm, L. and Tauson, R., 2011. High-fibre sunflower cake affects small intestinal digestion and health in broiler chickens. $\mathrm{Br}$. Poult. Sci. 52, 86-96.

Kang, S., Kim, D. H., Lee, S., Lee, T., Lee, K. W., Chang, H. H. \& Choi, Y. H.,2020. An acute, rather than progressive, increase in temperature-humidity index has severe effects on mortality in laying hens. Frontiers in Veterinary Science. 7, 853.

Khan, A. D., 2004. Making rice bran a cereals alternative. Feed Int. June, p. 18-19.

Kheravii, S. K., Swick, R. A., Choct, M., \& Wu, S. B., 2018. Upregulation of genes encoding digestive enzymes and nutrient transporters in the digestive system of broiler chickens by dietary supplementation of fiber and inclusion of coarse particle size corn. BMC genomics. 19(1), 1-14.

Koçer, B,, Bozkurt, M., Ege, G., Tüzün, A.E., 2021. Effects of sunflower meal supplementation in the diet on productive performance, egg quality and gastrointestinal tract traits of laying hens. Br Poult Sci. 62(1), 101-9.

Laudadio, V., Ceci, E., Lastella, N. M. B., \& Tufarelli, V., 2014. Effect of feeding lowfiber fraction of air-classified sunflower (Helianthus annus L.) meal on 
laying hen productive performance and egg yolk cholesterol. Poultry Science, 93(11), 2864-2869.

Lin, Y., Olukosi, O.A., 2021. Qualitative and quantitative profiles of jejunal oligosaccharides and cecal short-chain fatty acids in broiler chickens receiving different dietary levels of fiber, protein and exogenous enzymes. J Sci Food Agric. doi: 10.1002/jsfa.11165. Epub ahead of print. PMID: 33608932.

Luo, J., Yang, H. \& Song, B.L., 2020. Mechanisms and regulation of cholesterol homeostasis. Nat Rev Mol Cell Biol. 21, 225-245.

Mateos, G.G., Jiménez-Moreno, E., Serrano, M.P., Lázaro, R.P., 2012. Poultry response to high levels of dietary fiber sources varying in physical and chemical characteristics. J Appl Poult Res. 21(1), 156-74.

Menge, H., Littlefield, L. H., Frobish, L. T. and Weinland, B. T., 2012. Effect of Cellulose and cholesterol on blood and yolk lipids and reproductive efficiency of the hen. Nutrition Institute, Nonruminant Animal Nutrition Laboratory. The Journal of Nutrition.

Panaite, C. V., Dragotoiu D., Marti, R., Panaite T.D., 2015. Use of high fibre feedstuffs in layer diets starting with the starter stage. Archiva Zootechnica, 18(1), 53-63.

Panaite, T. D., Saracila, M., Papuc, C. P., Predescu, C. N., \& Soica, C. 2020. Influence of dietary supplementation of salix alba bark on performance, oxidative stress parameters in liver and gut microflora of broilers. Animals. 10(6), 958.

Pantaya, D., Effendi, R., Wulandari, S. \& Suryadi, U., 2020. The effect of wheat bran dietary fibre on cholesterol content of egg yolk laying ducks. IOP Conference Series: Earth and Environmental Science. 411. 012040. 10.1088/1755-1315/411/1/012040.

Praes, M.F.F.M., Junqueir,a O.M., Pereira, A.A., Filardi, R.S., Duarte, K.F., Sgavioli, S., Alva J.C.R., \& Domingues, C.H.F., 2014. High-fiber diets with reduced crude protein for commercial layers. Brazilian Journal of Poultry Science. 16(2), 43-49. https://doi.org/10.1590/1516-635x160243-50

Praes, M.F.F.M., Pereira, A.A., Sgavioli, S., Duarte, K.F., Alva, J.C.R., Domingues, C.H. de F., Puzzoti, M.M., Junqueira, O.M., 2011. Small intestine development of laying hens fed different fiber sources diets and crude protein levels Revista Brasileira de Ciência Avícola, vol. 13 issue, pp: 183-188, Published by Fundação APINCO de Ciência e Tecnologia Avícolas.

Raza, A., Bashir, S., \& Tabassum, R. 2019. An update on carbohydrases: growth performance and intestinal health of poultry. Heliyon. 5(4), e01437.

Röhe, I., Urban, J., Dijkslag, A., Te Paske, J., \& Zentek, J., 2019. Impact of an energyand nutrient-reduced diet containing $10 \%$ lignocellulose on animal performance, body composition and egg quality of dual purpose laying hens. Archives of animal nutrition. 73(1), 1-17. 
Sadeghi, A., Toghyani, M., Gheisari, A., 2015. Effect of various fiber types and choice feeding of fiber on performance, gut development, humoral immunity, and fiber preference in broiler chicks. Poultry Science. 94, 2734-2743.

Samli, H. E., Senkoylu, N., Akyurek, H. and Agma, A., 2006, Using rice bran in laying hen J. Cent. Euro. Agric. 7, 135-9.

Sateri, S., Seidavi, A., Bouyeh, M., Neumann, P., Kutzler, M., Laudadio, V.F., Tufarelli, V., 2017. Effect of olive meal and supplemental enzymes on performance traits, blood biochemistry, humoral immunity response and caecal microbiota of broilers. S. Afr. J. Anim. Sci., 47, 804-812.

Shi, S.R., Lu, J., Tong, H.B., Zou, J.M., \& Wang, K.H. 2012. Effects of graded replacement of soybean meal by sunflower seed meal in laying hen diets on hen performance, egg quality, egg fatty acid composition, and cholesterol content. J Appl Poult Res. 21(2), 367-374.

Singh, A. K. \& Kim, W. K. 2021. Effects of Dietary Fiber on Nutrients Utilization and Gut Health of Poultry: A Review of Challenges and Opportunities. Animals: an open access journal from MDPI. 11(1), 181. https://doi.org/10.3390/ani11010181

Sittiya, J., Yamauchi, K., \& Takata, K. 2016. Effect of replacing corn with whole-grain paddy rice and brown rice in broiler diets on growth performance and intestinal morphology. Journal of animal physiology and animal nutrition. 100(2), 381-390.

Sittiya, J., Yamauchi, K., Nimanong, W., Thongwittaya, N., 2020. Influence of levels of dietary fiber sources on the performance, carcass traits, gastrointestinal tract development, fecal ammonia nitrogen, and intestinal morphology of broilers. Rev. Bras. Cienc. Avic. 22, 1-8.

Souza, K.M.R., de, Faria, D.E., de Araújo, R.B., Sakamoto, M.I., Santos, T.T. dos, Kikuchi, C. de G., Nakashima, D.T., \& Caetano, V.C. ,2014. Performance and morphometry of the intestinal mucosa of laying hens fed diets containing xylanase. Brazilian Journal of Poultry Science. 16(3), 241-248.

Sousa, L. S., Carvalho, T. S. M., Nogueira, F. A., Saldanha, M. M., Vaz, D. P., Bertechini, A. G., Baião, N. C. and Lara, L. J. C., 2019. Fiber source and xylanase on performance, egg quality, and gastrointestinal tract of laying hens. Revista Brasileira de Zootecnia 48:e20170286.https://doi.org/10.1590/rbz4820170286

Sozcu, A., \& Ipek, A. Y. D. I. N., 2020. The effects of lignocellulose supplementation on laying performance, egg quality parameters, aerobic bacterial load of eggshell, serum biochemical parameters, and jejunal histomorphological traits of laying hens. Poultry Science. 99(6), 3179-3187.

Sugiharto, S., Yudiarti, T., Isroli, I., \& Widiastuti, E., 2018. The potential of tropical agro-industrial by-products as a functional feed for poultry. Iranian Journal of Applied Animal Science. 8(3), 375-385. 
Svihus, B., 2011. The gizzard: function, influence of diet structure and effects on nutrient availability. World's Poultry Science Journal. 67, 207-223.

Tejeda, J.O. and Kim, K.W. 2021. Role of Dietary Fiber in Poultry Nutrition. Animals. 11(2). 461. https://doi.org/10.3390/ani11020461

Tüzün, A. E., Koçer, B., Ege, G., \& Bozkurt, M., 2020. Influence of sunflower meal utilisation on growth performance and digestive tract traits of white strain pullets fed from 29 to $112 \mathrm{~d}$ of age. British Poultry Science. 1-8.

Wang, J., Kong, F., \& Kim, W. K., 2021. Effect of almond hulls on the performance, egg quality, nutrient digestibility, and body composition of laying hens. Poultry Science, 101286.

Willing, B.P., Van Kessel A.G., 2007. Enterocytes proliferation and apoptosis in the caudal small intestine is influenced by the composition of colonizing commensal bacteria in the neonatal gnotobiótic pig. Journal of Animal Science. 85(12), 3256-3266.

Yadav, S., \& Jha, R., 2019. Strategies to modulate the intestinal microbiota and their effects on nutrient utilization, performance, and health of poultry. Journal of Animal Science and Biotechnology. 10, 2. https://doi.org/10.1186/s40104-018-0310-9.

Yang, Y., Iji, P.A., Kocher, A., Mikkelsen, L.L., Choct M., 2008. Effects of xylanase on growth and gut development of broiler chickens given a wheat-based diet. Asian-Australasian Journal of Animal Science. 21(11), 1659- 1664.

Zare-Sheibani, A.A., Arab, M., Zamiri, M.J., 2015. Effects of extrusion of rice bran on performance and phosphorous bioavailability in broiler chickens. J. Anim. Sci. Technol. 57, 26 https://doi.org/10.1186/s40781-015-0059-z

Zarghi, H., 2018. Application of xylanas and $\beta$-glucanase to improve nutrient utilization in poultry fed cereal base diets: Used of enzymes in poultry diet. Insights in Enzyme Research. 2(1), 11-17.

Zhang, Y., Wang, J., \& Lin, D. K., 2005. Effects of alfalfa glycosides on performance, serum lipid and carcass quality in broilers. Acta Zoonutri Sinica. 17, 4650.

Zhou, X., Oryschak, M.A., Zijlstra, R.T., Beltranena, E., 2013. Effects of feeding highand low-fibre fractions of air-classified, solvent-extracted canola meal on diet nutrient digestibility and growth performance of weaned pigs. Anim. Feed Sci. Technol. 179, 112-120.

*** Regulation (CE) no. $152 / 2009$ (Sampling and analytical methods for the official inspection of feeds)

***Romanian laws (Law 206/2004, Ordinance 28/31.08.2011, Law 43/11.04.2014 and Directive 2010/63/EU 